\title{
ŚRODKI ZAPOBIEGAJĄCE NADUŻYCIOM W ZAKRESIE UCZESTNICTWA PRACOWNIKÓW W SPÓŁCE EUROPEJSKIEJ
}

\section{UWAGI OGÓLNE}

Spółka europejska (SE), wprowadzona na podstawie rozporządzenia 2157/2001 w sprawie statutu spółki europejskiej ${ }^{1}$, jest podmiotem gospodarczym, którego istotę stanowi ponadnarodowość. Charakter ponadnarodowy wskazanej spółki akcyjnej potwierdza oparcie jej funkcjonowania na akcie prawa europejskiego. Powyższy sposób regulacji umożliwił wprowadzenie wspólnych rozwiązań dla systemów prawa krajowego państw członkowskich Unii Europejskiej. Poza tym rozporządzenie 2157/2001 przewiduje, że siedziba spółki będzie zlokalizowana na terytorium Unii Europejskiej i tworzyć ja będą podmioty podlegające prawu przynajmniej dwóch państw członkowskich. Na europejską tożsamość spółki wskazuje również nazwa - Societas Europaea oraz utworzony od tej nazwy skrót SE, obowiązujące w sposób jednolity we wszystkich państwach członkowskich.

Od początku prac nad utworzeniem SE planowano zapewnić jej pracownikom mechanizm, przez który ich przedstawiciele mogliby mieć wpływ na decyzje, jakie mają być podjęte w ramach spółki. Kształt tego mechanizmu był przedmiotem sporu państw członkowskich przez prawie 31 lat. Największe kontrowersje dotyczyły rozwiązania polegającego na zapewnieniu pracownikom prawa do udziału w organach spółki². Ostatecznie w wyniku osiagniętego kompromisu politycznego przyjęto dyrektywę 2001/86 uzupełniająca statut spółki europejskiej w odniesieniu do uczestnictwa pracowników³, której przepisy regulują procedure zapewnienia im prawa do informowania, przeprowadzania konsultacji oraz partycypacji rozumianej jako prawo wyłonienia niektórych członków organu nadzorczego lub zarządzającego spółki (tzw. uczestnictwo pracowników). Wskazana regulacja została transponowana do

\footnotetext{
${ }^{1}$ Rozporządzenie Rady 2157/2001/WE z 8 października 2001 r. w sprawie statutu spółki europejskiej (SE), Dz. Urz. L 294 z 10 listopada 2001 r. ze zm., s. 1.

2 J. Wratny, Regulacja partycypacji pracowniczej w prawie wspólnotowym, „Praca i Zabezpieczenie Społeczne" 1993, nr 4, s. 4-5.

${ }^{3}$ Dyrektywa Rady 2001/86/WE z 8 października 2001 r. uzupełniająca statut spółki europejskiej w odniesieniu do uczestnictwa pracowników, Dz. Urz. UE L 294 z 10 listopada 2001 r.
} 
polskiego porządku prawnego w drodze ustawy z 4 marca 2005 r. o europejskim zgrupowaniu interesów gospodarczych i spółce europejskiej ${ }^{4}$.

W celu zabezpieczenia prawa pracowników do informowania, konsultacji i partycypacji w powołanej wyżej regulacji przewidziano ścisłe powiązanie uczestnictwa pracowników ze strukturą SE oraz szczegółowy charakter przepisów. Jednak prawodawca unijny, aby umożliwić indywidualizację konkretnych sytuacji i dostosowanie prawa do zmieniających się warunków, formułuje w powyższym celu dodatkowe zastrzeżenie w art. 11 dyrektywy 2001/86. Zgodnie z treścią tego przepisu państwa członkowskie przyjmują właściwe środki, zgodnie $\mathrm{z}$ prawem unijnym w celu zapobiegania nadużyciom SE do celów pozbawienia pracowników prawa do uczestnictwa pracowniczego lub zawieszenia takich praw.

Istotna jest ocena rzeczywistego wpływu cytowanego wyżej przepisu na zachowanie mechanizmów uczestnictwa pracowników w SE. W tym celu niezbędne jest wyjaśnienie pojęcia nadużycia w relacji z prawem Unii Europejskiej na przykładzie SE oraz ustalenie, jakie środki są przez prawodawcę uznawane za właściwe, aby przeciwdziałać pozbawieniu lub zawieszeniu prawa pracowników do uczestnictwa. Rozważania zostaną uzupełnione o badania empiryczne prowadzone na podstawie danych statystycznych dotyczacych funkcjonowania SE na rynku. Umożliwi to ustalenie w praktyce poziomu wykorzystania regulacji prawnej w celu obejścia przepisów o uczestnictwie pracowników.

\section{ZAKAZ STOSOWANIA NADUŻYĆ}

W art. 11 dyrektywy 2001/86 jednym z głównych pojęć jest termin „nadużycie SE". Wyjaśnienie jego znaczenia w rozumieniu wspomnianego wyżej przepisu wywołuje trudności, ponieważ należy ono do terminów prawa unijnego.

Po pierwsze, warto zauważyć, że w poszczególnych państwach członkowskich nie istnieje jedna koncepcja pojmowania pojęcia „nadużycia prawa". Obok siebie funkcjonują w Unii Europejskiej teoria subiektywna nadużycia prawa, według której jednym z elementów warunkujacym nadużycie jest zamiar szkody (np. Włochy, Austria) oraz teoria obiektywna, dla której przesądzające znaczenie podczas interpretacji nadużycia prawa posiadają elementy obiektywne, w tym rezultat, jaki został osiagnięty przez dane zachowanie (np. Niemcy, Hiszpania). Na tym tle wyraźnie odznaczają się te systemy prawa, które nie znają omawianego pojęcia (Wielka Brytania). W Polsce o nadużyciu prawa dyskutuje się w szczególności w kontekście nadużycia praw podmiotowych wszelkiego typu (majątkowych, niemajątkowych, względnych, bezwzględnych itp. - art. 5 k.c.) oraz obejścia prawa (działanie in fraudem

${ }^{4}$ Dz. U. Nr 62, poz. 551 ze zm. (dalej jako: u.s.e.).

${ }_{5}^{5}$ M. Godlewska, Pojęcie nadużycia prawa w prawie UE (cz. I), „Europejski Przegląd Sądowy” 2011, nr 6, s. 25. 
legis, np. art. 58 k.c. ${ }^{6}$. W tym kontekście nadużycie prawa polega na zachowaniu lub realizacji stanów rzeczy, które wykraczają poza treść danego prawa podmiotowego, co uznaje się za działanie bezprawne ${ }^{7}$.

Nie ulega również wątpliwości, że konstrukcja nadużycia prawa obecna jest także w polskim prawie pracy, w którym zastosowanie posiada art. $8 \mathrm{k} . \mathrm{p}$. będący w swojej treści odpowiednikiem art. 5 k.c. ${ }^{8}$ Zawarta jest w nim klauzula generalna, z której wynika, że nie korzysta z ochrony działanie sprzeczne z zasadami współżycia społecznego i społeczno-gospodarczym przeznaczeniem prawa. Wydaje się, że w celu wyjaśnienia pojęcia „nadużycie prawa” w kontekście uczestnictwa pracowników nie należy stosować krajowej wykładni odnoszącej się do aspektu etycznego i moralnego. Zasadniczo tego rodzaju interpretacja przewidziana jest dla pracowniczego stosunku pracy, rzadziej pojawiają się poglądy, w myśl których stosuje się ją również w ocenie działań podejmowanych w sferze zbiorowego prawa9. Artykuł 11 dyrektywy 2001/86, jak się wydaje, nie opiera się na powyższym rozumieniu nadużycia. Nie tyle chodzi w tym przepisie o subiektywny element oceny, co raczej o obiektywne kryteria służące wyjaśnieniu wskazanego terminu.

Po drugie, orzecznictwo Trybunału Sprawiedliwości Unii Europejskiej (TSUE) wskazuje na wiele różniących się od siebie kryteriów ustalenia, że doszło do „nadużycia prawa”. Specyfika tych kryteriów zależy nie tylko od konkretnego zachowania będącego przedmiotem oceny, ale także od gałęzi prawa, w której występuje „nadużycie”. Słuszna wydaje się krótka analiza wspomnianych kryteriów dokonana w celu ustalenia, które z nich są pomocne podczas wyjaśniania terminu „nadużycie”, zawartego w art. 11 dyrektywy 2001/86.

Wiele orzeczeń TSUE odnoszących się do nadużyć pojawia się w obszarze swobody przedsiębiorczości w zakresie prawa spółek. W części orzeczeń TSUE odwołuje się do takich przypadków nadużyć, które mają wiele wspólnego z oszustwem. Cechą wspólną tego rodzaju nadużyć jest celowe manipulowanie przez podmioty stanem faktycznym, a nie nadużycie prawa sensu stricto ${ }^{10}$. Przykładowo oszustwo obejmuje sztuczne kreowanie stanu faktycznego, tak aby zawierał on element transgraniczny. Jak uznał TSUE w sprawie Cadbury Schweppes ${ }^{11}$, do oszustwa dochodzi w przypadku założenia spółki, która nie prowadzi żadnej działalności gospodarczej (sztuczna struktura), ale chce przez element transgraniczny uniknaćc podlegania określonym przepisom pra-

${ }^{6}$ Zob. np. T. Stawecki, Obejście prawa. Szkic na temat granic prawa i zasad jego wyktadni, w: H. Izdebski, A. Stępkowski (red.), Nadużycie prawa. Materiały konferencyjne, Warszawa 2003, s. 87 i n.; A. Szpunar, Nadużycie prawa podmiotowego, Kraków 1947.

7 M. Pyziak-Szafnicka, Prawo podmiotowe, „Studia Prawa Prywatnego” 2006, nr 1, s. 100.

${ }^{8}$ M. Gersdorf, Nadużycie prawa w prawie pracy, w: H. Izdebski, A. Stępkowski (red.), op. cit., s. 133 i 134 .

9 Eadem, Kontrowersje $w$ zakresie stosowania konstrukcji nadużycia prawa $w$ prawie pracy indywidualnym i zbiorowym, „Studia Iuridica Lublinensia” 24, 2015, s. 45.

10 M. Godlewska, op. cit., s. 27.

11 Wyrok TSUE z 12 września 2006 r. w sprawie C-196/04, Cadbury Schweppes v Commissioners of Inland Revenue, Zb. Orz. 2006, s. I-07995, pkt 55. 
wa krajowego. W tej sytuacji rozważane są elementy subiektywne w postaci woli (intencji), tak aby nie było wątpliwości co do zaistnienia oszustwa ${ }^{12}$. Wydaje się, że w art. 11 dyrektywy 2001/86 nie chodzi o oszustwa w powyższym rozumieniu.

W innych orzeczeniach TSUE zastanawiał się, czy nie jest nadużyciem prawa brak prowadzenia rzeczywistej działalności gospodarczej przez spółkę w kraju pochodzenia, a wykonywanie tejże działalności w innym państwie. W tym kontekście na oznaczenie działalności takich spółek Trybunał w wyrokach w sprawach Segers ${ }^{13}$, Centros $^{14}$ oraz Inspire Art ${ }^{15}$ nie używa jednak określenia nadużycie prawa, ale uznaje tę sytuację za „korzystanie ze swobody przedsiębiorczości zagwarantowanej w traktacie”. Z wymienionych orzeczeń wynika w sposób oczywisty, że tzw. wtórna swoboda przedsiębiorczości nie tylko umożliwia zakładanie tego rodzaju spółek, ale również zezwala na przenoszenie siedziby spółki bez konieczności likwidacji tego podmiotu lub utworzenia nowej osoby prawnej. Pod wpływem orzecznictwa uprawnienie to, w odniesieniu do SE, zostało wyraźnie zapisane w art. 8 zd. 1 rozporządzenia 2157/2001, w myśl którego statutowa siedziba SE może zgodnie z ust. 2-13 zostać przeniesiona do innego państwa członkowskiego. Prowadzi to do wniosku, że w świetle art. 11 dyrektywy 2001/86 przeniesienie siedziby statutowej spółki do innego państwa niż miejsce jej założenia i rozpoczęcie tam działalności gospodarczej nie może być traktowane jako nadużycie prawa.

Wydaje się, że konstrukcja art. 11 dyrektywy 2001/86, a przede wszystkim użyty w tym przepisie termin „nadużycie SE”, wskazuje na mniej szczegółowe i dokładne sformułowanie prawodawcy. Prowadzi to do wniosku, że art. 11 dyrektywy 2001/86 nie zawiera własnej instytucji prawnej i powinien być interpretowany przez pryzmat celów prawodawcy unijnego zawartych w omawianej dyrektywie. Potwierdza to również wyrok TSUE w sprawie Centros, w którym zawarte zostały istotne wskazówki co do wyjaśnienia pojęcia „nadużycie prawa”. Zgodnie z pierwszą z tez wyroku nadużyciem prawa sa zachowania wykraczające poza cele, które mają realizować przepisy prawa unijnego. W myśl zaś drugiej z tez nadużyciem prawa są zachowania, których celem (efektem) jest naruszenie praw osób trzecich. Za wskazaną interpretacją art. 11 dyrektywy 2001/86 przemawia również długa historia prac nad dyrektywa, zakończona kompromisem politycznym. Częścią tego kompromisu wydaje się treść art. 11 dyrektywy 2001/86, w którym prawodawca unijny stara się zapobiegać

12 M. Rehberg, Die missbräuchliche Verkürzung der unternehmerischen Mitbestimmung durch die Societas Europaea, „Zeitschrift für Unternehmens- und Gesellschaftsrecht” 2005, z. 6, s. 865 .

${ }^{13}$ Wyrok TSUE z 10 lipca 1986 r. w sprawie 79/85, D.H.M. Segers v Bestuur van de Bedrijfsvereniging voor Bank- en Verzekeringswezen, Groothandel en Vrije Beroepen, ECR 1986, s. 02375, pkt 16.

${ }^{14}$ Wyrok TSUE z 9 marca 1999 r. w sprawie C-212/97, Centros Ltd v Erhvervs- og Selskabsstyrelsen, ECR 1999, s. I-1459, pkt 27.

15 Wyrok TSUE z 30 września 2003 r. w sprawie C-167/01, Kamer van Koophandel en Fabrieken voor Amsterdam v Inspire Art Ltd., ECR 2003, s. I-10155, pkt 138. 
wszelkim lukom regulacyjnym ${ }^{16}$. W ogólnym rozumieniu nadużyciem będzie zatem wykorzystywanie formalnych możliwości prawa sprzecznych z jego założeniami.

Szczególne znaczenie dla art. 11 dyrektywy 2001/86 posiada pkt 18 preambuły tejże dyrektywy, który wyraźnie formułuje zarówno cel dyrektywy jak i zasadę „przed i po”. Celem dyrektywy 2001/86, jak stanowi pkt 18, jest ochrona nabytych praw pracowników w odniesieniu do uczestnictwa w podejmowaniu decyzji przez spółkę. Z kolei w myśl zasady „przed i po” prawa pracowników istniejące przed utworzeniem spółek europejskich powinny stanowić podstawę praw pracowników w zakresie uczestnictwa w SE. W konsekwencji, według prawodawcy unijnego, takie podejście powinno mieć zastosowanie nie tylko do wstępnego utworzenia SE, ale także zmian strukturalnych w istniejącej SE oraz do spółek, na które miały wpływ procesy związane ze zmianami strukturalnymi (pkt $18 \mathrm{zd}$. 3 preambuły dyrektywy 2001/86). Z cytowanej treści pkt 18 wynika konieczność porównania zrestrukturyzowanej SE z „oryginalną” SE oraz ze spółkami uczestniczącymi $\mathrm{w}$ jej tworzeniu pod katem istnienia odpowiedniego poziomu praw pracowniczych $^{17}$. Szczegółowo procedurę tego porównania regulują art. 3-7 dyrektywy 2001/86 dotyczace procedury negocjacyjnej i zasad standardowych w odniesieniu do uczestnictwa pracowników.

\section{DANE STATYSTYCZNE A PRZYPADKI DĄŻENIA DO POMINIĘCIA UCZESTNICTWA PRACOWNIKÓW W SPÓŁCE EUROPEJSKIEJ}

Wiele niepokojących zjawisk w zakresie uczestnictwa pracowników widocznych jest już na przykładzie danych statystycznych dotyczących funkcjonowania SE na rynku. W wyniku analizy tych danych pojawia się wattpliwość, czy w praktyce w niektórych przypadkach nie daży się do tego, aby uniknaćc uczestnictwa pracowników zarówno podczas zakładania SE, jak i w trakcie późniejszej jej działalności.

Na marginesie rozważań warto zauważyć, że dane statystyczne dotyczące SE zostały opracowane przez European Trade Union Institute (ETUI - Europejski Instytut Związków Zawodowych). W 2003 r. ETUI założył SE Europe Network $^{18}$ (Sieć SE Europe) w celu obserwowania firm, które utworzyły lub planują ustanowić SE.

Zgodnie z danymi statystycznymi na 31 marca 2017 r. ogólna liczba zarejestrowanych spółek europejskich wyniosła 2757. W porównaniu z latami poprzednimi zauważa się stały wzrost liczby tworzonych spółek europejskich.

\footnotetext{
${ }_{16}$ M. Rehberg, op. cit., s. 870-871.

17 Ibidem, s. 879.

18 W kwietniu 2017 r. sieć zmieniła nazwę na Worker Participation Europe Network.
} 


\section{Tabela 1}

Rozkład geograficzny SE

\begin{tabular}{|c|c|c|c|}
\hline Państwo & $\begin{array}{l}\text { Liczba SE zareje- } \\
\text { strowanych } \\
\text { w poszczególnych } \\
\text { państwach }\end{array}$ & $\begin{array}{l}\text { Liczba SE zatrud- } \\
\text { niających powyżej } \\
5 \text { pracowników } \\
\text { - tzw. normal SEs }\end{array}$ & $\begin{array}{l}\text { Empty, shelf } \\
\text { i UFO SE }\end{array}$ \\
\hline Czechy & 1898 & $90(5,00 \%)$ & $1808(95,00 \%)$ \\
\hline Niemcy & 411 & $232(56,00 \%)$ & $179(44,00 \%)$ \\
\hline Słowacja & 123 & $13(10,50 \%)$ & $110(89,50 \%)$ \\
\hline Wielka Brytania & 42 & $14(34,00 \%)$ & $28(66,00 \%)$ \\
\hline Francja & 35 & $24(68,00 \%)$ & $11(32,00 \%)$ \\
\hline Holandia & 30 & $16(53,00 \%)$ & $14(47,00 \%)$ \\
\hline Luksemburg & 26 & $12(46,00 \%)$ & $14(54,00 \%)$ \\
\hline Austria & 24 & $11(46,00 \%)$ & $13(54,00 \%)$ \\
\hline Cypr & 24 & $9(37,50 \%)$ & $15(62,50 \%)$ \\
\hline Liechtenstein & 11 & $2(18,00 \%)$ & $9(82,00 \%)$ \\
\hline Belgia & 11 & $4(36,00 \%)$ & $7(64,00 \%)$ \\
\hline Irlandia & 9 & $2(22,00 \%)$ & $7(78,00 \%)$ \\
\hline Estonia & 8 & $7(87,50 \%)$ & $1(12,50 \%)$ \\
\hline Malta & 7 & $0(0,00 \%)$ & $7(100,00 \%)$ \\
\hline Szwecja & 5 & $2(40,00 \%)$ & $3(60,00 \%)$ \\
\hline Węgry & 5 & $4(80,00 \%)$ & $1(20,00 \%)$ \\
\hline Łotwa & 5 & $3(60,00 \%)$ & $2(40,00 \%)$ \\
\hline Polska & 5 & $1(20,00 \%)$ & $4(80,00 \%)$ \\
\hline Norwegia & 4 & $2(50,00 \%)$ & $2(50,00 \%)$ \\
\hline Estonia & 3 & $0(0,00 \%)$ & $3(100,00 \%)$ \\
\hline Litwa & 2 & $1(50,00 \%)$ & $1(50,00 \%)$ \\
\hline Włochy & 2 & $1(50,00 \%)$ & $1(50,00 \%)$ \\
\hline Finlandia & 1 & $1(100,00 \%)$ & $0(0,00 \%)$ \\
\hline Portugalia & 1 & $0(0,00 \%)$ & $1(100,00 \%)$ \\
\hline Grecja & 1 & $0(0,00 \%)$ & $1(100,00 \%)$ \\
\hline Dania & 1 & $0(0,00 \%)$ & $1(100,00 \%)$ \\
\hline Bułgaria & 1 & $0(0,00 \%)$ & $1(100,00 \%)$ \\
\hline Ogólem: & 2757 & $451(16,00 \%)$ & $2306(84,00 \%)$ \\
\hline
\end{tabular}

Źródło: opracowanie własne na podstawie danych ETUI.

Analiza danych zawartych w tabeli 1 prowadzi do wniosku, że najwięcej SE od kilku już lat rejestrowanych jest w Czechach (1898) i w Niemczech (411). Z przeprowadzonych badań wynika, że w danym roku w Czechach rejestrowano zawsze więcej SE niż we wszystkich pozostałych państwach członkowskich 
- w 2017 r. w Czechach było ich 45, a w pozostałych państwach - 15; w 2016 odpowiednio 149 i 88 (ETUI 2017). Jak się wydaje, jednym z powodów niezwykłej ekspansji spółek europejskich w Czechach są ułatwienia podatkowe oraz uproszczone procedury dotyczące $\mathrm{SE}^{19}$. Niezmiennie od lat do krajów, które przodują w liczbie zakładanych SE, należą również Słowacja (123) i Wielka Brytania (42). Eacznie w wymienionych czterech krajach istnieją 2474 SE. Warto zauważyć, że w porównaniu z 2014 r. szczególny wzrost liczby zarejestrowanych SE nastapił w Liechtensteinie: z 6 do 11 (prawie o 100\%) oraz w Polsce: z 2 do 5 (blisko 150\%) ${ }^{20}$. Ponadto SE pojawiły się także w krajach, w których do 2014 r. nie zarejestrowano żadnej takiej spółki: w Bułgarii (1) i Grecji (1). Nadal jednak nie zarejestrowano żadnej spółki europejskiej w czterech krajach EOG. Należą do nich Chorwacja, Islandia, Rumunia i Słowenia.

Należy podkreślić, że wyraźne jest zjawisko zdecydowanie przeważającej liczby empty SEs, czyli spółek, które są aktywne, ale nie zatrudniają pracowników; shelf SEs - nieaktywnych, tzw. sleeping beauties (,śpiących piękności”), oraz UFO SEs, które nie występują ${ }^{21}$. Obecnie tylko 451 SE (16\%) zatrudnia więcej niż 5 pracowników i prowadzi działalność gospodarczą (normal SEs). Z przeprowadzonych badań wynika, że najwięcej tzw. normal SEs niezmiennie od lat zakładanych jest na terenie Niemiec (232). Interesujące i warte podkreślenia jest to, że tego rodzaju spółki stanowią ponad połowę ogólnej liczby $\mathrm{SE}$ rejestrowanych w tym kraju. Odmienna relacja występuje w Republice Czeskiej, gdzie liczba normal SEs stanowi niecałe 5\% wszystkich zakładanych w tym kraju spółek (90).

Przedstawione dane moga prowadzić do wniosku, że zdecydowana większość SE jest zakładana w taki sposób, aby uniemożliwić uczestnictwo w nich pracowników. Dotyczy to spółek, które nie zatrudniaja przynajmniej 5 pracowników. Powyższe zjawisko nie jest jednak traktowane przez państwa członkowskie jako nadużycie SE, o którym stanowią art. 11 i pkt 18 preambuły dyrektywy 2001/86. Zdaniem sądów niemieckich warunek rejestracji SE uzależniający tę rejestrację od uregulowania mechanizmów uczestnictwa pracowników (art. 12 rozporządzenia 2157/2001) opiera się na założeniu, że zarówno spółki uczestniczące ${ }^{22}$, jak i spółka europejska zatrudniają pracowników. W sytuacji, w której ani spółki uczestniczące, ani SE nie zatrudniają pracowników, w ocenie judykatury niemieckiej swoboda przedsiębiorczości przemawia za rezygnacją z wymogu uregulowania uczestnictwa pracowników przed wpisem SE do rejestru. W mojej ocenie, jeżeli zarejestrowana w ten sposób SE

${ }^{19}$ Przykładowo wskazanie notariusza, a nie sądu rejestrowego jako podmiotu właściwego do wydawania zaświadczeń potwierdzających dopełnienie aktów i czynności prawnych.

${ }^{20}$ Dane z badań prowadzonych do 2014 r.: A. Giedrewicz-Niewińska, Udziat pracowników $w$ nadzorze korporacyjnym $w$ spółce europejskiej, w: A. Balcerzak (red.), 8 Międzynarodowa Konferencja z cyklu Współczesne zjawiska w gospodarce. Rzad czy rynek?: 18-19 czerwca 2015, Toruń 2015.

${ }^{21}$ Podział SE zaproponowany przez B. Keller, F. Werner, The establishment of the European company: the first cases form an industrial relations perspective, „European Journal of Industrial Relations" 14(2), 2008, s. 154.

${ }^{22}$ Przez spółkę uczestniczącą należy rozumieć spółkę bezpośrednio uczestniczącą w powstaniu SE (art. 2 lit. b dyrektywy 2001/86). 
następnie zatrudniłaby pracowników, stanowiłoby to nadużycie wymagające zastosowania właściwych środków w rozumieniu art. 11 dyrektywy 2001/86 ${ }^{23}$.

Tabela 2

Uczestnictwo pracowników w SE

\begin{tabular}{|l|l|}
\hline \multicolumn{2}{|c|}{ Ogólna liczba SE - 2757, } \\
w tym liczba SE bez uczestnictwa pracowników - 2624 \\
\hline Liczba SE z informacja, konsultacją i partycypacja - 64 & $\begin{array}{l}\text { Liczba SE z informacją } \\
\text { i konsultacja - 69 }\end{array}$ \\
\hline $\begin{array}{l}\text { Narodowość przedstawicieli pracowników: } \\
\text { Niemcy - 142, pozostałe kraje - 46 (w tym Holandia, Francja - 7, } \\
\text { Wielka Brytania - 6, Austria - 5, Polska - 4, Belgia - 3, Czechy, } \\
\text { Węgry, Szwecja, Rumunia - 2, Słowacja, Włochy, Dania, Portugalia, } \\
\text { Szwajcaria, USA - 1) }\end{array}$ \\
\hline
\end{tabular}

Źródło: opracowanie własne na podstawie danych ETUI.

Jak pokazują dane statystyczne zawarte w tabeli 2, uczestnictwo pracowników może być analizowane jedynie w 451 zarejestrowanych SE jako „normalnych”. Okazuje się, że wśród tych SE tylko 133 mają uzgodnienia dotyczące uczestnictwa pracowników na poziomie transnarodowym. W ponad połowie $\mathrm{z}$ nich (69) wdrożona jest procedura informowania i przeprowadzania konsultacji bez zapewnienia udziału pracowników w organie spółki. Partycypacja pracownicza jako najsilniejsza forma uczestnictwa istnieje jedynie w 67 SE. Z danych statystycznych (ETUI) wynika, że najczęściej przedstawiciele pracowników w zarządzie pojawiają się w SE zarejestrowanych na terenie Niemiec (np. w ADAC, AL-KO KOBER, Allianz Global Corporate \& Specialty, MAN Diesel \& Turbo, MAN, Porsche Automobil Holding, PUMA, Zalando).

Tabela 3

Formy założenia SE

\begin{tabular}{|c|c|c|c|c|}
\hline \multicolumn{5}{|c|}{ Formy założenia SE - 2757 } \\
\hline SE zależne & $\begin{array}{c}\text { SE przekształ- } \\
\text { cone }\end{array}$ & $\begin{array}{c}\text { SE forma } \\
\text { nieznana }\end{array}$ & SE połaczone & SE holding \\
\hline $79 \%$ & $8 \%$ & $8 \%$ & $4 \%$ & $1 \%$ \\
\hline \multicolumn{5}{|c|}{ Formy założenia tzw. normalnych SE - 454 } \\
\hline SE zależne & $\begin{array}{c}\text { SE przekształ- } \\
\text { cone }\end{array}$ & SE połączone & $\begin{array}{c}\text { SE forma } \\
\text { nieznana }\end{array}$ & SE holding \\
\hline $40 \%$ & $35 \%$ & $16 \%$ & $7 \%$ & $2 \%$ \\
\hline
\end{tabular}

Źródło: opracowanie własne na podstawie danych ETUI.

${ }^{23}$ Szerzej na ten temat A. Giedrewicz-Niewińska, Uczestnictwo pracowników w spótce europejskiej, Warszawa 2015, s. 348 i 349. 
Dążenie do pominięcia uczestnictwa pracowników w spółce europejskiej może pojawić się także przez odpowiednie wykorzystanie form zakładania SE. Z rozporządzenia 2157/2001 wynikają cztery różne sposoby jej zakładania: połączenie, przekształcenie, zależność i holding. Należy podkreślić, że w zależności od sposobu założenia SE inaczej kształtuje się ochrona udziału pracowników w jej zarządzaniu. Największa ochrona występuje w przypadku SE powstałej w drodze przekształcenia. Wówczas nie istnieje możliwość „ucieczki” od partycypacji, nawet w drodze negocjacji stron porozumienia w sprawie mechanizmów uczestnictwa pracowników w SE (art. 4 ust. 4 dyrektywy 2001/86). Wyjątek stanowi sytuacja, w której w spółce przekształcanej pracownikom nie przysługiwało prawo udziału w jej organach. W praktyce jest to tylko częściowo preferowany sposób rejestracji SE (8\%); analiza danych z tabeli 3 nie pozostawia wątpliwości, że najczęściej wykorzystywanym sposobem jej utworzenia (79\% i 40\%) jest SE zależna. Ten sposób założenia SE stanowi wraz z holdingiem najsłabsze zabezpieczenie prawa udziału pracowników w organie spółki. Wpływa na to regulacja, w myśl której obowiązek kontynuacji tego prawa w przypadku stosowania zasad standardowych pojawia się dopiero przy wysokim progu 50\% pracowników objętych partycypacją w spółkach uczestniczących (art. 7 ust. 2 dyrektywy 2001/86).

Jako przykład dążenia do uniknięcia partycypacji pracowników przez odpowiednią formę założenia SE można by potraktować sytuację, w której niemiecka spółka $A$ będąca koncernem i zapewniająca partycypację pracowników, aby utworzyć SE bez udziału pracowników w zarządzaniu zakłada $\mathrm{z}$ angielska spółką $B$ SE w formie holdingu.

Przypadki, w których dąży się do pominięcia partycypacji pracowników w organach SE mogą pojawić się również w wyniku dokonywania kolejnych zmian strukturalnych SE, w tym także przeniesienia jej siedziby. Przykładowo przypadek taki zachodzi wówczas, gdy akcjonariusze spółki niemieckiej $A$ z zapewniona partycypacją pracowników, zakładają angielską spółkę $B$ oraz irlandzką spółkę $D$ i następnie kupują od osób trzecich wolną od partycypacji spółkę europejską $C$. Następnie przenoszą oni siedzibę spółki europejskiej $C$ do Niemiec i przekształcają spółkę $A$ w spółkę europejską $C^{24}$.

Tabela 4

Przekształcone lub zlikwidowane SE w latach 2004-2016

\begin{tabular}{|c|c|}
\hline Poszczególne lata & $\begin{array}{c}\text { Liczba przekształconych } \\
\text { lub zlikwidowanych SE }\end{array}$ \\
\hline 2004 (październik-grudzień) & 2 \\
\hline 2005 & 9 \\
\hline 2006 & 12 \\
\hline 2007 & 16 \\
\hline
\end{tabular}

${ }^{24}$ M. Rehberg, op. cit., s. 861. 
cd. tab. 4

\begin{tabular}{|c|c|}
\hline 2008 & 17 \\
\hline 2009 & 18 \\
\hline 2010 & 13 \\
\hline 2011 & 15 \\
\hline 2012 & 41 \\
\hline 2013 & 5 \\
\hline 2014 & 4 \\
\hline 2015 & 1 \\
\hline 2016 (do III kwartału) & 0 \\
\hline
\end{tabular}

Źródło: opracowanie własne na podstawie danych ETUI.

W praktyce okazuje się, że tego rodzaju zmiany strukturalne nie sa powszechne. Jak wynika z tabeli 4, na 2800 istniejacych w latach 2004-2016 SE przekształconych zostało (ogółem) - 35, zlikwidowanych zaś - 118. Dane ETUI pokazują również, że ze wszystkich zarejestrowanych SE przeniesienia siedziby w latach 2004 - I kwartał 2017 (włączając w to również przekształcenie i likwidację SE) dokonało 129 SE (4\%). Najwięcej SE przeniosło swoje siedziby do innego kraju z Holandii (29), Wielkiej Brytanii (23), Luksemburga (19) i Niemiec (14). Z kolei najwyższy wskaźnik siedzib SE przenoszonych do danego kraju odnotowały: Wielka Brytania (25), Czechy (18), Luksemburg (15), Austria (12) i Niemcy (14).

\section{ZAKRES PRZEPISÓW DOTYCZĄCYCH NADUŻYĆ SE W USTAWIE O EUROPEJSKIM ZGRUPOWANIU INTERESÓW GOSPODARCZYCH I SPÓŁCE EUROPEJSKIEJ}

Z art. 11 dyrektywy 2001/86 wynika, że państwa członkowskie przyjmuja właściwe środki, zgodnie z prawem unijnym, aby zapobiegać nadużyciom SE w celu pozbawienia pracowników prawa do uczestnictwa pracowniczego lub zawieszenia takich praw. Oznacza to, że to państwo członkowskie, a nie prawo unijne czy orzecznictwo TSUE, powinno wskazywać, jak będzie się bronić przed ewentualnymi nadużyciami prawa UE. Z drugiej jednak strony prawodawca unijny zwraca uwagę, że przyjęcie tych środków przez państwo członkowskie powinno nastapić zgodnie z prawem unijnym.

Powstaje pytanie, jak powinna wyglądać relacja między prawem unijnym a prawem krajowym ustalajacym sankcje za nadużycie. Trybunał Sprawiedliwości Unii Europejskiej w cytowanym wyroku w sprawie Centros podaje dwie wytyczne interpretacyjne co do warunków, jakie powinny spełniać przepisy prawa krajowego czy praktyka w celu przeciwdziałania nadużyciom prawa. Po pierwsze, nie mogą one prowadzić do całkowitego zablokowania swobody 
przedsiębiorczości przez - przykładowo - praktykę odmawiania rejestracji oddziału spółki, której siedziba znajduje się w innym państwie członkowskim. Po drugie, nadużycie prawa powinno być zawsze badane przez szczegółowa analizę faktów związanych z danym przypadkiem i w kontekście tego, czy w efekcie tych działań nastapiło pokrzywdzenie interesów osób trzecich. Prowadzi to do wniosku o konieczności stosowania przez państwo członkowskie takich środków, którym nie zostanie zarzucona oczywista nieproporcjonalność i które uwzględnią specyficzne cechy prawa UE, w szczególności jego efektywność, pierwszeństwo i potrzebę jednolitego stosowania ${ }^{25}$. Prawo krajowe wprowadzajace sankcje za nadużycie prawa nie może zatem udaremniać unijnego celu przepisów ani naruszać ich jednolitego stosowania w państwach członkowskich.

Polskie przepisy implementujące dyrektywę 2001/86 nie przewidują w pełni, w mojej ocenie, proporcjonalnych środków prawnych przeciwdziałajacych zamiarowi pozbawienia lub ograniczenia praw pracowników w zakresie zaangażowania ${ }^{26}$. Z kolei za zgodne z wytycznymi TSUE należy uznać środki wskazane w art. 120 u.s.e. Przepis ten stanowi, że w przypadku zmian wskazujących na zamiar pozbawienia lub ograniczenia praw pracowników w zakresie zaangażowania przeprowadza się negocjacje, których celem jest zawarcie porozumienia określającego zasady zaangażowania pracowników w SE w zmienionych warunkach. Ponadto w cytowanym przepisie polski ustawodawca skonkretyzował zakres przedmiotowy art. 11 dyrektywy 2001/86 i pkt 18 zd. 3 preambuły tego aktu, wskazujacc, jakie istotne zmiany w SE, jej spółkach zależnych lub zakładach następujące po rejestracji SE uprawniają do zastosowania środków zapobiegających nadużyciom. Wymieniono w tym przypadku zmiany dotyczące ich struktury, liczby pracowników, a w przypadku SE - także zmianę miejsca jej rejestracji.

Wątpliwości pojawiają się jednak w sytuacji, w której w SE obowiązuja zasady standardowe. Według art. 121 u.s.e. w przypadkach określonych w art. 84-86 do zaangażowania pracowników w zmienionych warunkach stosuje się przepisy działu 4 niniejszego tytułu w takim zakresie, w jakim zmiany zagrażają pozbawieniem lub ograniczeniem praw pracowników. Lakoniczność cytowanego przepisu sprawia trudności w ustaleniu, jakie w praktyce środki prawne przewidział ustawodawca polski w przypadku nadużyć SE, w której obowiąuja zasady standardowe. Należy zauważyć, że w dziale 4 nie przewidziano wprost możliwości podjęcia negocjacji z właściwym organem SE nad porozumieniem w sprawie zaangażowania pracowników. Możliwość taka przewiduje polski ustawodawca, ale wyłącznie po upływie określonego czasu,

${ }^{25}$ Wyroki TSUE: z 12 maja 1998 r. w sprawie 367/96, Alexandros Kefalas i in. v Elliniko Dimosio (państwo greckie) i Organismos Oikonomikis Anasygkrotisis Epicheiriseon AE (OAE), ECR 1998, s. I-02843 oraz z 23 marca 2000 r. w sprawie C-373/97, Dionysios Diamantis v Elliniko Dimosio (państwo greckie) and Organismos Ikonomikis Anasygkrotisis Epicheiriseon AE (OAE), ECR 2000, s. I-01705, pkt 34.

${ }^{26}$ Terminem „zaangażowanie pracowników” posługuje się u.s.e. na określenie prawa pracowników do informacji, konsultacji i uczestnictwa, umożliwiające im wywieranie wpływu na decyzje podejmowane w SE (art. 58 ust. 8 tej ustawy). 
tj. w razie upływu czteroletniego okresu funkcjonowania organu przedstawicielskiego i stosowaniu zasad standardowych w SE (art. 96 u.s.e.). W innym z kolei przepisie polski ustawodawca przewiduje weryfikację liczby członków organu przedstawicielskiego i podziału miejsc w tym organie co dwa lata, stosownie do zmiany liczby pracowników zatrudnionych w SE, jej spółkach zależnych i zakładach (art. 89 u.s.e.).

$\mathrm{W}$ przypadku wystapienia istotnej zmiany liczby pracowników zatrudnionych w SE, jej spółkach zależnych i zakładach przepis ten stanowi, że właściwy organ SE zwraca się do przedstawicieli pracowników (lub bezpośrednio do pracowników) o ponowne wyłonienie członków organu przedstawicielskiego. Powyższa regulacja nie rozstrzyga jednak zasadniczej wątpliwości, jaka procedura przeciwdziałania nadużyciom obowiązuje w przypadkach, w których zmiany zagrażające pozbawieniem lub ograniczeniem praw pracowników nie wynikają ze zmiany liczby pracowników, a są spowodowane zmianami w zakresie struktury i miejsca rejestracji SE.

Wydaje się, że właściwym rozwiązaniem de lege ferenda $\mathrm{w}$ przypadku nadużyć SE w celu pozbawienia lub ograniczenia praw pracowników w zakresie zaangażowania (zarówno w czasie obowiązywania porozumienia, jak i zasad standardowych) byłaby konieczność wznowienia negocjacji. Skoro procedura negocjacyjna (zakończona porozumieniem lub wdrożeniem zasad standardowych) jest podstawowym i wystarczającym środkiem, aby zapewnić realizację celu dyrektywy 2001/86, to stanowi również właściwy środek w przypadku próby obejścia prawa. Z kolei na skuteczność renegocjacji jako środka odstraszającego od próby nadużyć SE wskazuje także aspekt finansowy tej procedury ${ }^{27}$.

W związku z powyższym należałoby, moim zdaniem, de lege ferenda potraktować nadużycie jako odrębny powód wznowienia negocjacji także w przypadku obowiązywania w SE zasad standardowych. Z inicjatywą rozpoczęcia takich negocjacji mógłby wystapić zarówno organ SE, jak i organ przedstawicielski. Zamiast specjalnego zespołu negocjacyjnego ponowne negocjacje mogłyby wspólnie prowadzić organ przedstawicielski wraz z przedstawicielami pracowników dotkniętych planowaną zmiana, niereprezentowanych dotychczas w organie przedstawicielskim ${ }^{28}$.

\section{UWAGI KOŃCOWE}

Z przeprowadzonych rozważań wynika, że art. 11 dyrektywy 2001/86 nie zawiera własnej instytucji prawnej. Sformułowany w tym przepisie zakaz nadużywania SE do celów pozbawienia lub zawieszenia prawa pracowników do uczestnictwa powinien być interpretowany, jak wynika z orzecznictwa TSUE,

27 Tak też M. Rehberg, op. cit., s. 877.

${ }^{28}$ Podobne rozwiąanie znajduje się w prawie niemieckim (§ 18 ust. 3 Gesetz vom 22. Dezember 2004 über die Beteiligung der Arbeitnehmer in einer Europäischen Gesellschaft (SE-Beteiligungsgesetz - SEBG; BGBI. I S. 3675, 3686). 
z perspektywy celu, który mają realizować przepisy prawa unijnego, oraz faktu, że określone zachowanie narusza prawa osób trzecich.

Cel dyrektywy 2001/86 został wyrażony w pkt 18 jej preambuły jako ochrona nabytych praw pracowników w odniesieniu do uczestnictwa w podejmowaniu decyzji przez spółkę. Ustalenie, kiedy zatem doszło do nadużyć SE, wymaga porównania praw pracowników istniejących przed utworzeniem spółki europejskiej z prawami pracowników w zakresie uczestnictwa w SE (zasada „przed i po”). Ponadto pkt 18 preambuły zd. 3 dyrektywy 2001/86, uzupełniając brzmienie art. 11 tej dyrektywy dodaje, że porównanie to powinno mieć zastosowanie nie tylko do etapu tworzenia SE, ale także do zmian strukturalnych w istniejaccej już SE.

Analiza danych statystycznych dotyczacych zakładania i funkcjonowania SE prowadzi do wniosku, że może dochodzić do nadużyć SE w celu pozbawienia lub zawieszenia prawa pracowników do uczestnictwa. Jak wynika z przeprowadzonych badań, wraz z rosnacą liczbą SE następuje zróżnicowany wzrost udziału pracowników w podejmowaniu decyzji w spółce. Uzależnienie rejestracji SE od uregulowania mechanizmu uczestnictwa pracowników nie spowodowało proporcjonalnego do liczby zakładanych SE wzrostu poziomu tego uczestnictwa. W tym przypadku widoczna jest inwencja przedsiębiorców, którzy poszukują narzędzi optymalizacji korzyści wynikających z prowadzonej przez nich działalności gospodarczej przez usunięcie „hamulcowego kierowcy” utworzenia $\mathrm{SE}^{29}$, jak nazywane jest uczestnictwo pracowników. W tym przypadku ucieczka od uczestnictwa pracowników odbywa się w drodze zakładania SE niezatrudniającej pracowników lub wyboru takiego sposobu jej założenia, który gwarantuje jak najmniejszy jego poziom. $\mathrm{Na}$ podstawie danych statystycznych wydaje się, że w mniejszym zakresie dochodzi do pozbawienia lub zawieszenia praw pracowników do uczestnictwa w wyniku zmian strukturalnych w istniejacej $\mathrm{SE}$.

W konsekwencji konieczne jest zastosowanie właściwych środków w celu przeciwdziałania nadużyciom. Środki proporcjonalne do zakładanego przez dyrektywę celu w postaci renegocjacji przewiduje polski ustawodawca w sytuacji, w której w SE zasady uczestnictwa zostały ustalone w porozumieniu pomiędzy specjalnym zespołem negocjacyjnym a właściwymi organami spółek uczestniczacych. Niedostateczne środki, w kontekście orzecznictwa unijnego, proponuje ustawa o spółce europejskiej w czasie obowiązywania w SE zasad standardowych. De lege ferenda wydaje się, że w przypadku nadużyć SE w celu pozbawienia lub ograniczenia praw pracowników w zakresie zaangażowania w czasie obowiązywania zasad standardowych pożądane byłoby również wprowadzenie obowiązku wznowienia negocjacji.

dr hab. Aneta Giedrewicz-Niewińska

Uniwersytet $w$ Biatymstoku

a.niewinska@uwb.edu.pl

${ }_{29}$ W. Njoya, Employee ownership in the European company: reflexive law, reincorporation and escaping co-determination, „Journal of Corporate Law Studies” 11(2), 2011, s. 271. 


\section{MEASURES PREVENTING THE ABUSE OF EMPLOYEE PARTICIPATION IN A EUROPEAN COMPANY}

\section{Summary}

A unique feature of EU law on the European Company (EC) is that it is closely linked to employee participation from the moment of its creation. The participation mechanism enables employees to influence decisions made within the company. Since providing employees with the right to participate often prolongs the procedure for setting up an EC, some entrepreneurs are seeking ways to circumvent this mechanism. The aim of this study is therefore to determine what is meant by the abusive behaviour of an EC that may lead to the deprivation or suspension of the right and what legal remedies are considered appropriate under EU law to counteract it. The implementation of the objectives will be based not only on the analysis of the legal regulations and case law of the CJEU, but also on the practice of European companies operating on the market. 